\title{
Heterometallic $\mathrm{Ru}_{2} \mathrm{Co}_{2}[2 \times 2]$ Grid with \\ Localized Single Molecule Magnet Behaviour
}

\author{
Joanne W. L. Wong, Serhiy Demeshko, Sebastian Dechert, and Franc Meyer*
}

Universität Göttingen, Institut für Anorganische Chemie, Tammannstr. 4,

D-37077 Göttingen, Germany

\section{Supporting Information}

1. Materials and Methods

2. Complex Synthesis

S2

3. Mass Spectrometry

4. ${ }^{1}$ H NMR Spectroscopy

5. EPR Spectroscopy

6. Cyclic Voltammetry

S8

7. Spectro-electrochemistry

8. X-ray Crystallography

9. Magnetic Measurements 


\section{Materials and Methods}

All reactions were carried out under dry nitrogen using standard Schlenk techniques. Solvents were dried and degassed by standard procedures before use. Starting materials were purchased from commercial sources and used as received. The ligand HL was synthesized according to literature procedures. ${ }^{1}$ UV-vis spectra of solutions were recorded with a Varian Cary 50 Bio Spectrophotometer at room temperature. NMR spectra were recorded on Bruker AvanceIII 300, AvanceIII 400, and Bruker AvanceIII $500 \mathrm{MHz}$ spectrometers. EPR spectra were measured on a Bruker ELEXSYS E500 spectrometer, equipped with a digital temperature control system ER 4131VT using nitrogen as coolant and simulated with EasySpin. ${ }^{2}$ All spectra at low temperatures were recorded at $9.42 \mathrm{GHz}$ microwave frequency, $4.00 \mathrm{G}$ field modulation amplitude, $100 \mathrm{kHz}$ field modulation frequency, and $9.87 \mathrm{~mW}$ microwave power. Chemical shifts $(\delta)$ are given in ppm relative to residual solvent signals of $\mathrm{CD}_{3} \mathrm{CN}$ and $\mathrm{CDCl}_{3}$. Electron ionization (EI) mass spectra were recorded with a Finnigan MAT 8200 and Electrospray ionization (ESI) mass spectra with a Finnigan MAT LCQ mass spectrometer. Cyclic voltammetry experiments were performed with the Gamry Interface 1010 and analyzed using the Gamry Framework program. A three electrode setup was used: glassy carbon as the working electrode, $\mathrm{Ag}$ wire as the reference electrode and $\mathrm{Pt}$ wire as the counter electrode in $\mathrm{CH}_{3} \mathrm{CN} / 0.1$ $\mathrm{M} \mathrm{Bu} 4 \mathrm{NPF}_{6}$. Ferrocene was used as the internal standard. Despite several attempts, no satisfactory $\mathrm{CHN}$ combustion analyses could be obtained for $\mathbf{1}, \mathbf{2}$ and $\mathbf{3}$, even when using highly crystalline material (giving consistent values that did not match well the calculated ones). We attribute this to the high fluorine content of these compounds that have 4 or $6 \mathrm{BF}_{4}^{-}$anions per cationic grid molecule.

\section{Complex Synthesis}

Preparation of $\left[\mathbf{H L}_{2} \mathbf{R u}\right]\left(\mathbf{B F}_{4}\right)_{2} \mathbf{2}(\mathbf{1}) . \mathrm{HL}(0.378 \mathrm{~g}, 1.06 \mathrm{mmol}, 3$ eq. $)$ and $\mathrm{Ru}(\mathrm{DMSO})_{4} \mathrm{Cl}_{2}(0.162$ g, $0.334 \mathrm{mmol}, 1$ eq.) were suspended in degassed $\mathrm{EtOH}$ :acetone $(24 \mathrm{~mL})$ then heated at reflux for 16 hours to give a deep brown solution. Subsequently, the reaction was cooled to room temperature, $\mathrm{NH}_{4} \mathrm{BF}_{4}(0.112 \mathrm{~g}, 1.07 \mathrm{mmol}, 3.2$ eq.) was added and the crude product was obtained by precipitation with $\mathrm{Et}_{2} \mathrm{O}$. Red crystalline material was obtained by slow diffusion of $\mathrm{Et}_{2} \mathrm{O}$ into a solution of 1 in $\mathrm{MeCN}(0.293 \mathrm{~g}, 0.277 \mathrm{mmol}, 78 \%$ yield).

${ }^{1} \mathrm{H}$ NMR $\left(300 \mathrm{MHz}, \mathrm{CD}_{3} \mathrm{CN}\right): \delta(\mathrm{ppm})=15.08(\mathrm{~s}, 1 \mathrm{NH}), 8.60(\mathrm{dd},, J=5.3,3.7 \mathrm{~Hz}, 1 \mathrm{Ar}-\mathrm{H})$, $8.10(\mathrm{~s}, 1 \mathrm{Ar}-\mathrm{H}), 8.03$ (t, $J=7.9,1 \mathrm{Ar}-\mathrm{H}), 7.86$ (dd, $J=7.9,0.9 \mathrm{~Hz}, 1 \mathrm{Ar}-\mathrm{H}), 7.82-7.70$ (m, 3 Ar-H), 2.67 (s, $\left.1 \mathrm{CH}_{3}\right), 7.54(\mathrm{~d}, J=8.0 \mathrm{~Hz}, 1 \mathrm{Ar}-\mathrm{H}), 7.48$ (d, $\left.J=8.0,1 \mathrm{Ar}-\mathrm{H}\right), 7.42$ (td, $J=7.7$, 
$1.8 \mathrm{~Hz}, 1 \mathrm{Ar}-\mathrm{H}), 7.24$ (td, $J=7.9,1.5 \mathrm{~Hz}, 1 \mathrm{Ar}-\mathrm{H}), 6.84$ (dt, $J=4.5,1.5 \mathrm{~Hz}, 1 \mathrm{Ar}-\mathrm{H}), 6.78$ (ddd, $J=7.5,5.6,1.3 \mathrm{~Hz}, 1 \mathrm{Ar}-\mathrm{H}), 6.72-6.59(\mathrm{~m}, 2 \mathrm{Ar}-\mathrm{H})$.

$\operatorname{MS}(\operatorname{ESI}(+), \mathrm{MeCN}): m / z=458\left[(\mathrm{HL})_{4} \mathrm{Ru}_{2} \mathrm{FNa}\right]^{4+}, m / z=853\left[(\mathrm{HL})_{2} \mathrm{Ru}\right]^{2+}$

UV-Vis $(\mathrm{MeCN}, 298 \mathrm{~K}): \lambda[\mathrm{nm}]\left(\varepsilon\left[\mathrm{M}^{-1} \mathrm{~cm}^{-1}\right]\right)=434$ (27660), 457 (26700), 514 (11250), 554 (7290).

Preparation of $\left[\mathbf{L}_{4} \mathbf{R u}_{2} \mathrm{Co}_{2}\right]\left(\mathrm{BF}_{4}\right)_{4}$ (2). The Ru${ }^{\mathrm{II}}$ corner complex $\mathbf{1}$ (0.118 g, $0.114 \mathrm{mmol}, 1$ eq.) and $\mathrm{NaO}^{t} \mathrm{Bu}(0.029 \mathrm{~g}, 0.301 \mathrm{mmol}, 2.6$ eq.) were dissolved in dry $\mathrm{MeCN}$ (8 mL). After one hour, $\mathrm{Co}\left(\mathrm{BF}_{4}\right)_{2}(0.078 \mathrm{~g}, 0.229 \mathrm{mmol}, 2$ eq. $)$ was added and the reaction was heated at reflux for two days. Subsequently, the brown solution was cooled to room temperature, filtered, and the crude product was obtained by precipitation with $\mathrm{Et}_{2} \mathrm{O}$. Crystalline material was obtained by slow diffusion of $\mathrm{Et}_{2} \mathrm{O}$ into a solution of 2 in $\mathrm{MeCN}(0.067 \mathrm{~g}, 0.031 \mathrm{mmol}, 27 \%$ yield $)$.

${ }^{1} \mathrm{H}$ NMR $\left(400 \mathrm{MHz}, \mathrm{CD}_{3} \mathrm{CN}\right): \delta(\mathrm{ppm})=120.28(\mathrm{~s}, 1 \mathrm{Ar}-\mathrm{H}), 97.69(\mathrm{~s}, 1 \mathrm{Ar}-\mathrm{H}), 66.67(\mathrm{~s}, 1 \mathrm{Ar}-$ H), 48.49 (s, 1 Ar-H), 29.64 (s, 1 Ar-H), 27.15 (s, 1 Ar-H), 25.91 (s, 1 Ar-H), 11.90 (s, 1 ArH), 6.34 (s, 1 Ar-H), -2.91 (s, 1 Ar-H), -4.14 (s, 1 Ar-H), -9.38 (s, 1 Ar-H), -17.10 (s, 1 Ar-H), -22.44 (s, 1 Ar-H).

$\operatorname{MS}(\operatorname{ESI}(+), \mathrm{MeCN}): m / z=455\left[\mathrm{Ru}_{2} \mathrm{Co}_{2}\right]^{4+}$

UV-vis (MeCN, $298 \mathrm{~K}): \lambda[\mathrm{nm}]\left(\varepsilon\left[\mathrm{M}^{-1} \mathrm{~cm}^{-1}\right]\right)=235$ (81670), 267 (65560), 299 (61930), 408 (17770), 496 (8010), 608 (3040).

Preparation of [ $\left.\mathbf{L}_{4} \mathbf{R u}_{2} \mathrm{Co}_{2}\right]\left(\mathrm{BF}_{4}\right)_{6}$ (3). Complex 2 (0.020 g, 0.009 mmol, 1 eq.) was dissolved dry $\mathrm{MeCN}$ (3 ml). Subsequently, a solution of [thianthrenium ']BF 4 (0.006 g, 0.018 mmol, 2 eq.) was added to immediately give a red solution. The reaction was stirred at room temperature for 16 hours, filtered and precipitated with $\mathrm{Et}_{2} \mathrm{O}$ to give a red powder. Crystalline material was obtained by slow diffusion of $\mathrm{Et}_{2} \mathrm{O}$ into a solution of 3 in $\mathrm{MeCN}$ ( $5 \mathrm{mg}, 0.002 \mathrm{mmol}, 25 \%$ yield).

${ }^{1} \mathrm{H}$ NMR $\left(400 \mathrm{MHz}, \mathrm{CD}_{3} \mathrm{CN}\right): \delta(\mathrm{ppm})=8.68(\mathrm{~d}, J=8.0 \mathrm{~Hz}, 1 \mathrm{Ar}-\mathrm{H}), 8.57(\mathrm{~s}, 1 \mathrm{Pyz}-\mathrm{H}), 8.47$ (m, 2 Ar-H), 8.38 (t, $J=8.0,1$ Ar-H), 8.21 (m, 2 Ar-H), 7.97 (d, $J=7.2$ Hz, 1 Ar-H), 7.73 (t, $J$ $=7.7 \mathrm{~Hz}, 1 \mathrm{Ar}-\mathrm{H}), 7.56(\mathrm{t}, J=7.8,1 \mathrm{Ar}-\mathrm{H}), 7.37(\mathrm{~d}, J=7.8 \mathrm{~Hz}, 1 \mathrm{Ar}-\mathrm{H}), 6.91(\mathrm{t}, J=6.9 \mathrm{~Hz}, 1$ Ar-H), 6.73 (t, $J=6.8 \mathrm{~Hz}, 1 \mathrm{Ar}-\mathrm{H}), 5.73$ (d, $J=6.0,1 \mathrm{Ar}-\mathrm{H}), 5.49$ (d, $J=6.1,1 \mathrm{Ar}-\mathrm{H})$.

$\operatorname{MS}(\mathrm{ESI}(+), \mathrm{MeCN}): m / z=455\left[\mathrm{~L}_{4} \mathrm{Ru}_{2} \mathrm{Co}_{2}\right]^{4+}$ 


\section{Mass Spectrometry}

(a)

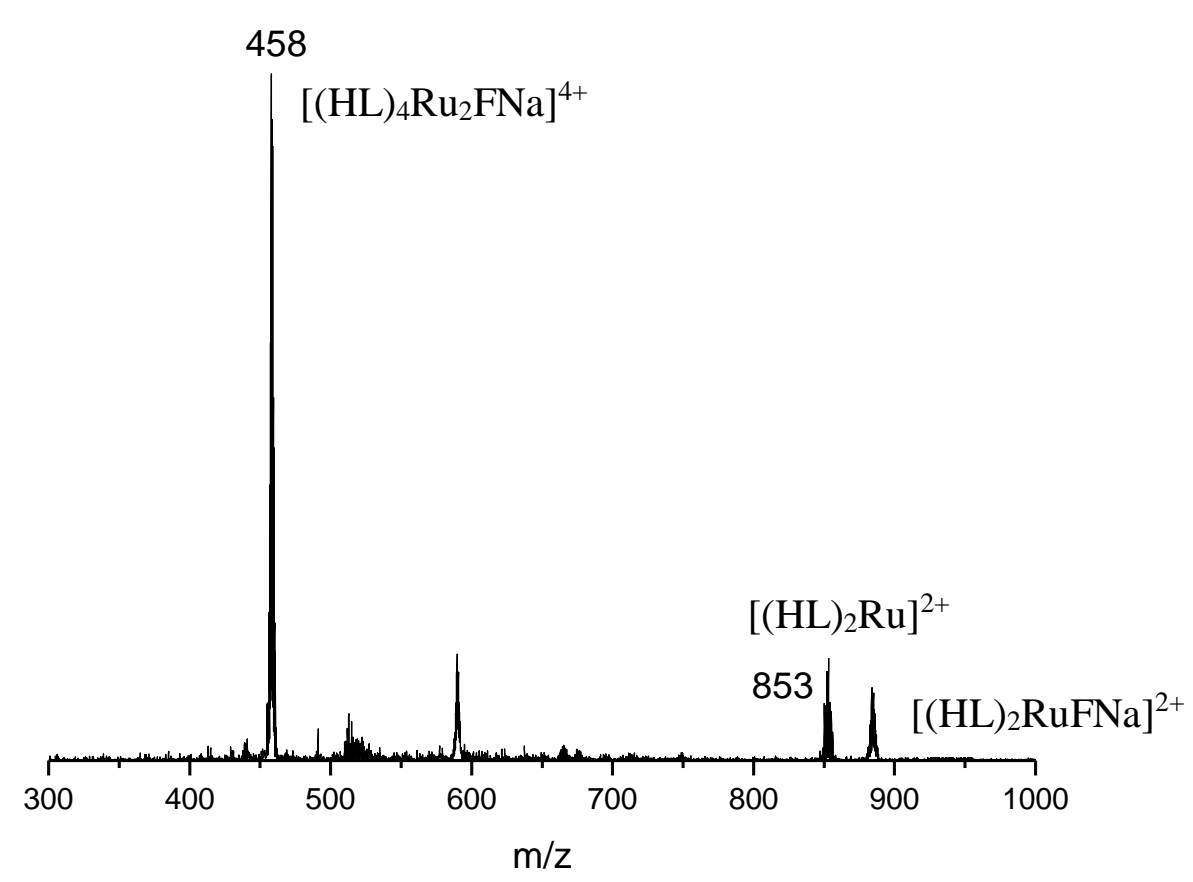

(b)

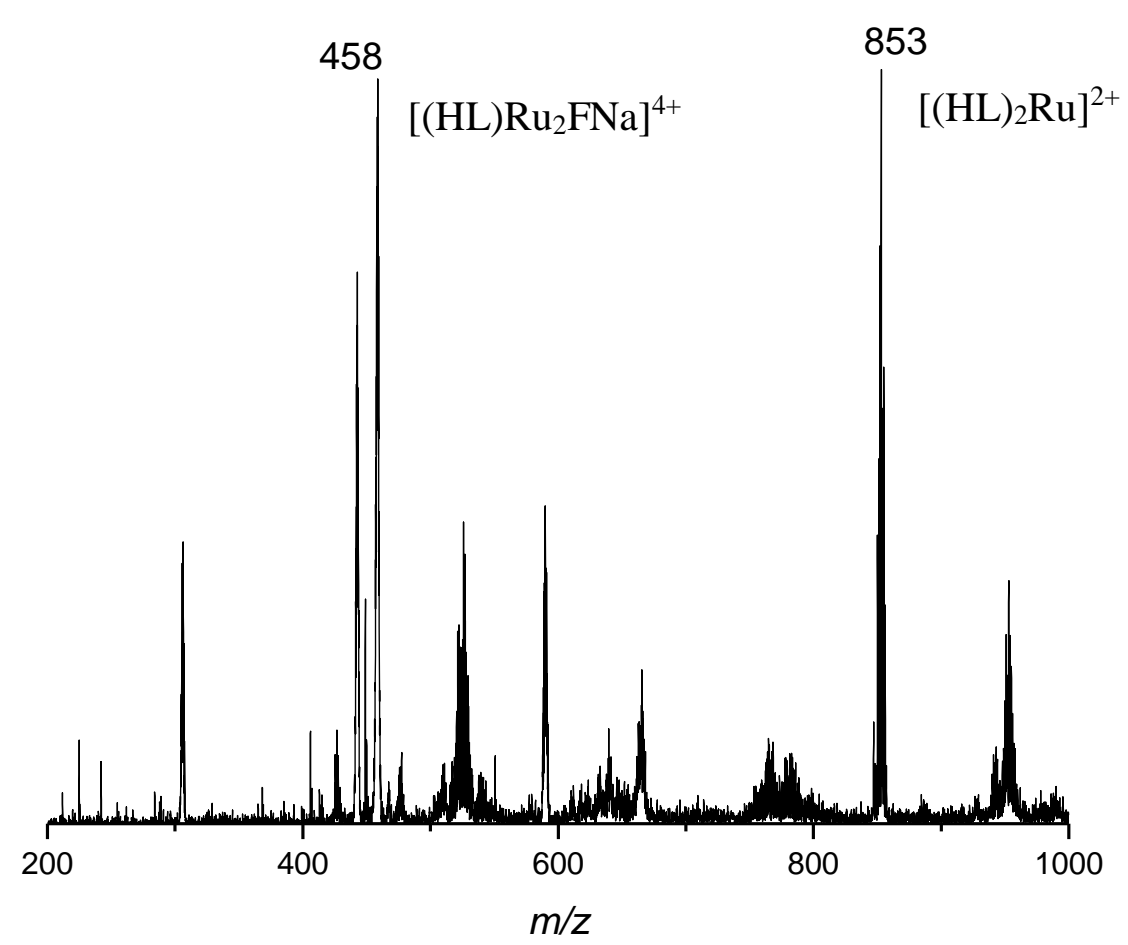

Figure S1. Mass spectrometry of $\mathbf{1}$ in (a) concentrated solutions and (b) in dilute solution of $\mathrm{MeCN}$, illustrating the concentration dependence for the monomer and dimer. 


\section{4. ${ }^{1}$ H NMR Spectroscopy}
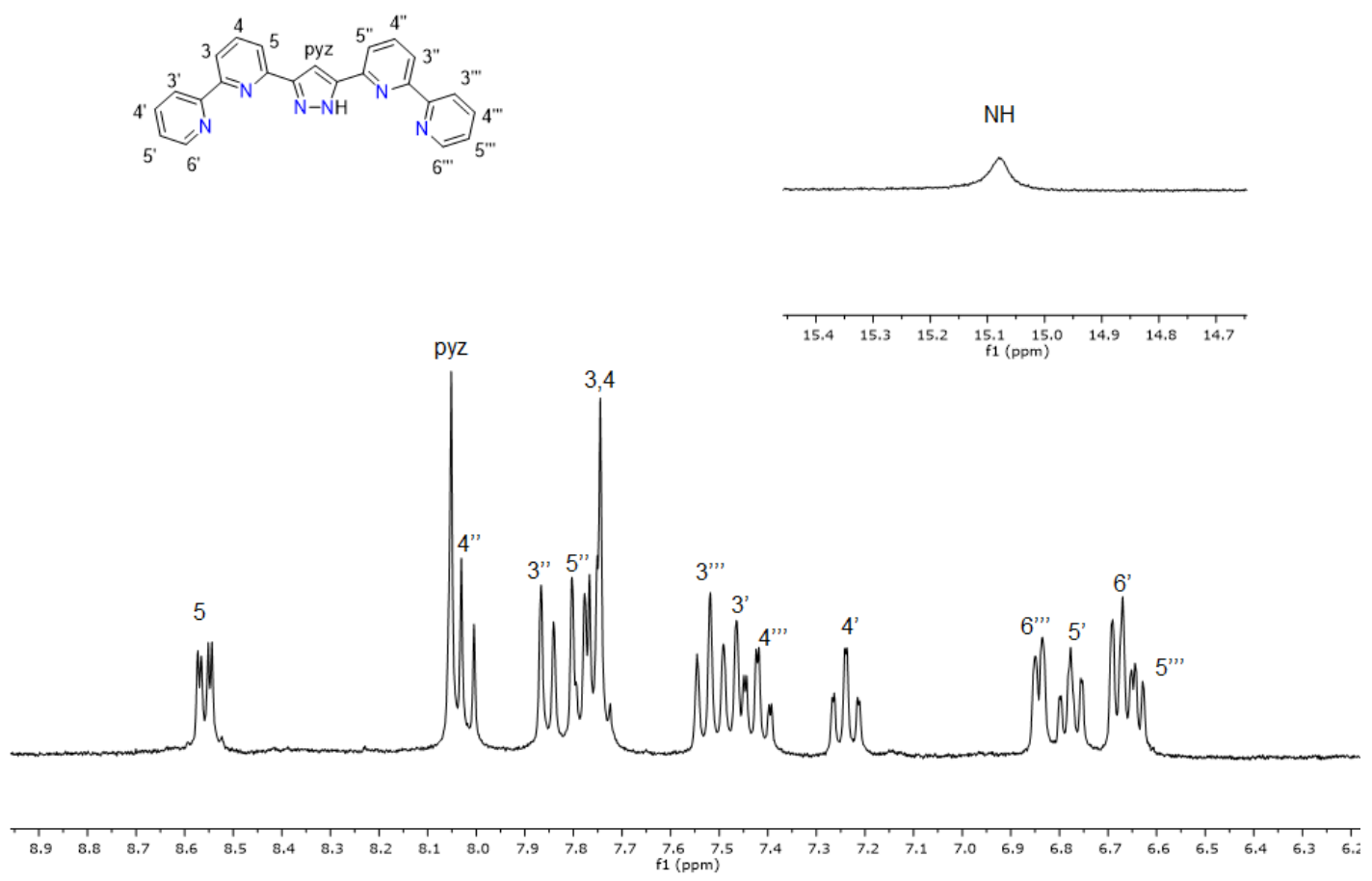

Figure S2. ${ }^{1} \mathrm{H}$ NMR spectrum of 1 in $\mathrm{MeCN}-\mathrm{d}_{3}$ at room temperature.
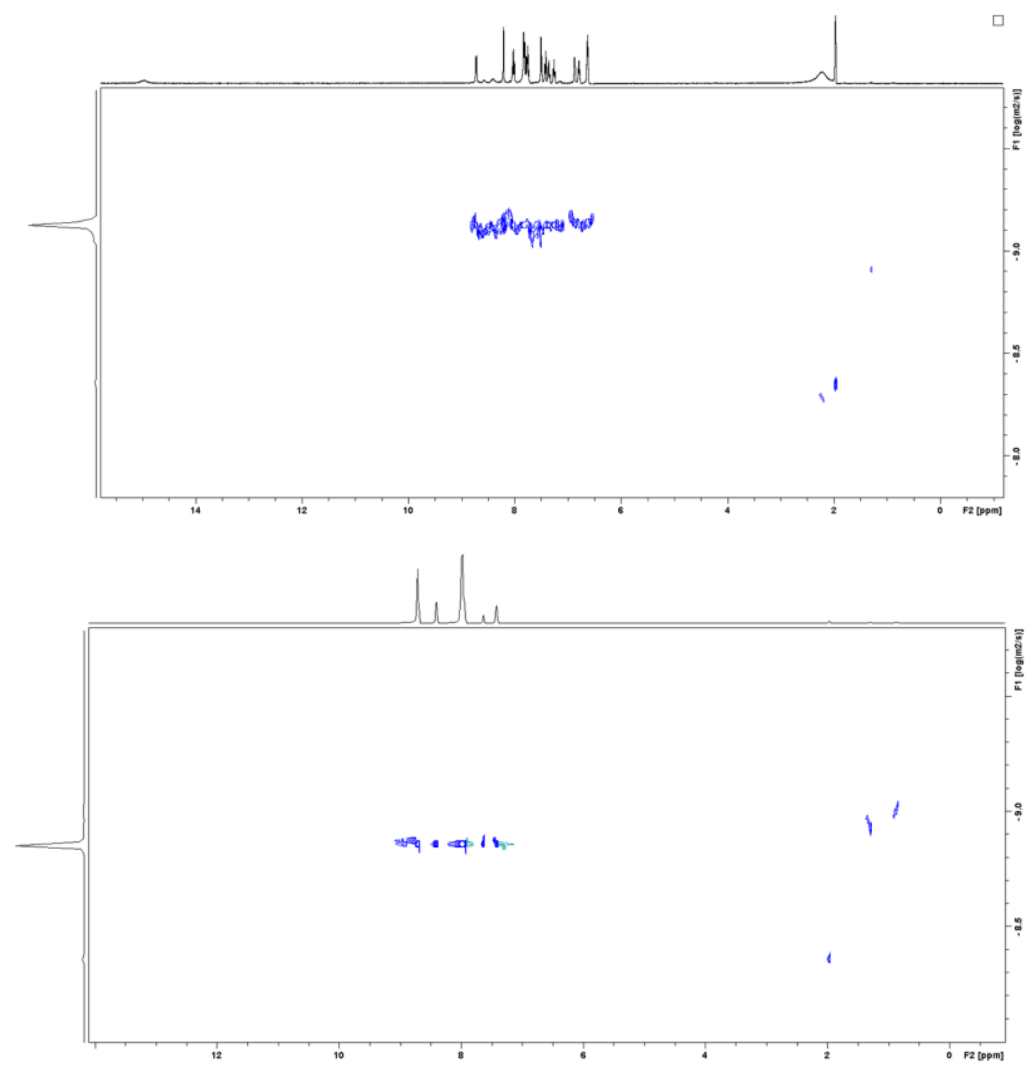

Figure S3. DOSY experiments on the (a) $\mathrm{Ru}^{\mathrm{II}}$ "corner complex" $\mathbf{1}$ and (b) the ligand HL in $\mathrm{CDCl}_{3}: \mathrm{CD}_{3} \mathrm{CN}(1: 1)$ at $323 \mathrm{~K}$. Using the Einstein-Stokes equation, the ratio of the hydrodynamic volumes of both compounds was determined to be 5.428 suggesting the presence of a dimer of 1 in solution. 
Table S1. Diffusion coefficient and calculated hydrodynamic radius for $\mathbf{1}$ and HL.

\begin{tabular}{ccc}
\hline & $\boldsymbol{D}\left[\mathbf{m}^{\mathbf{2}} \mathbf{s}^{-1}\right]$ & $\mathbf{r}_{\mathbf{s}}[\AA]$ \\
\hline $\mathbf{1}$ & $7.15 \times 10^{-10}$ & 7.086 \\
HL & $1.33 \times 10^{-9}$ & 4.032 \\
\hline
\end{tabular}
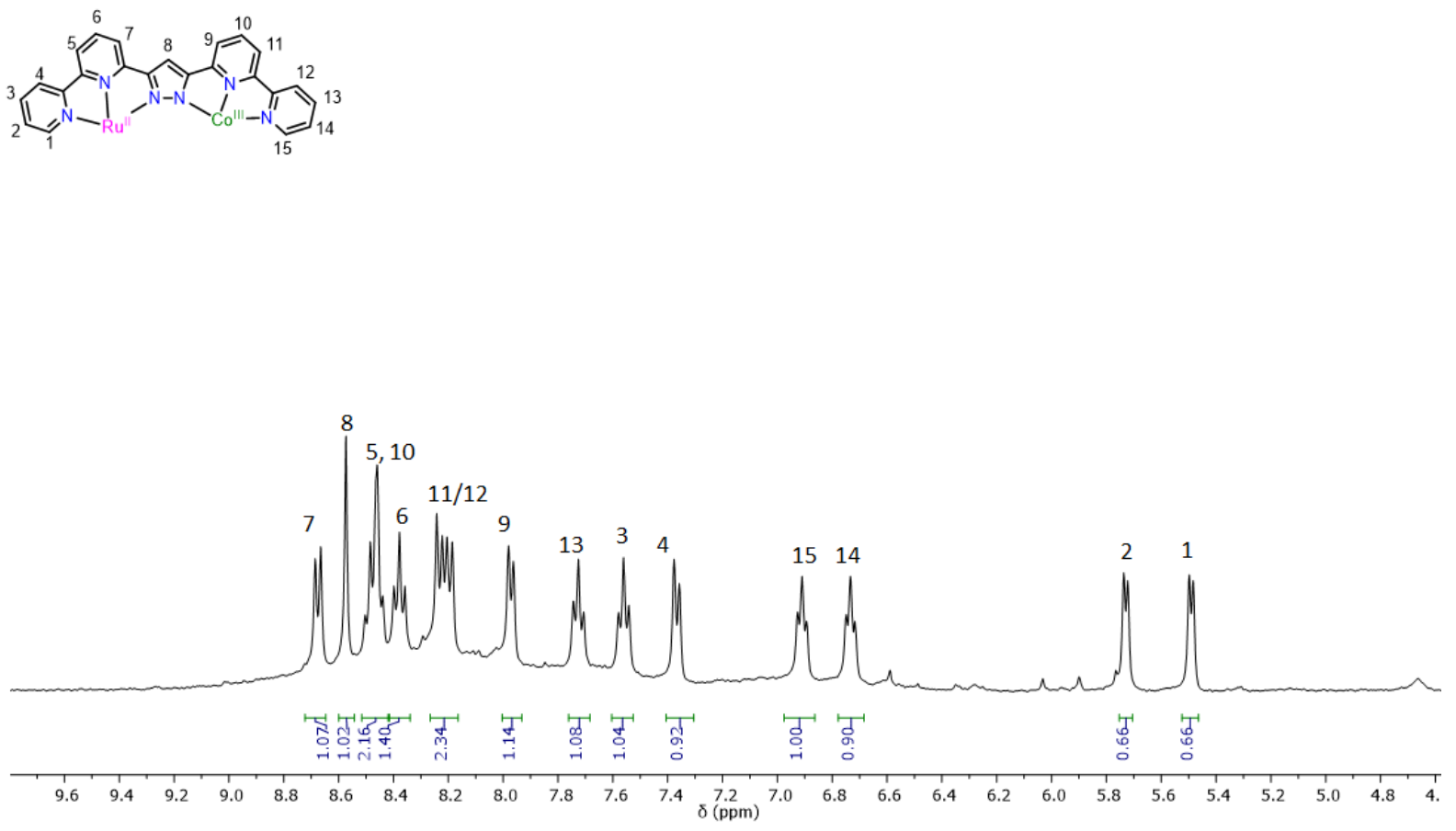

Figure S4. ${ }^{1} \mathrm{H}$ NMR spectrum of $\left[\mathrm{L}_{4} \mathrm{Ru}_{2} \mathrm{Co}_{2}\right]\left(\mathrm{BF}_{4}\right)_{6}(3)$ in $\mathrm{MeCN}-\mathrm{d}_{3}$ at room temperature.

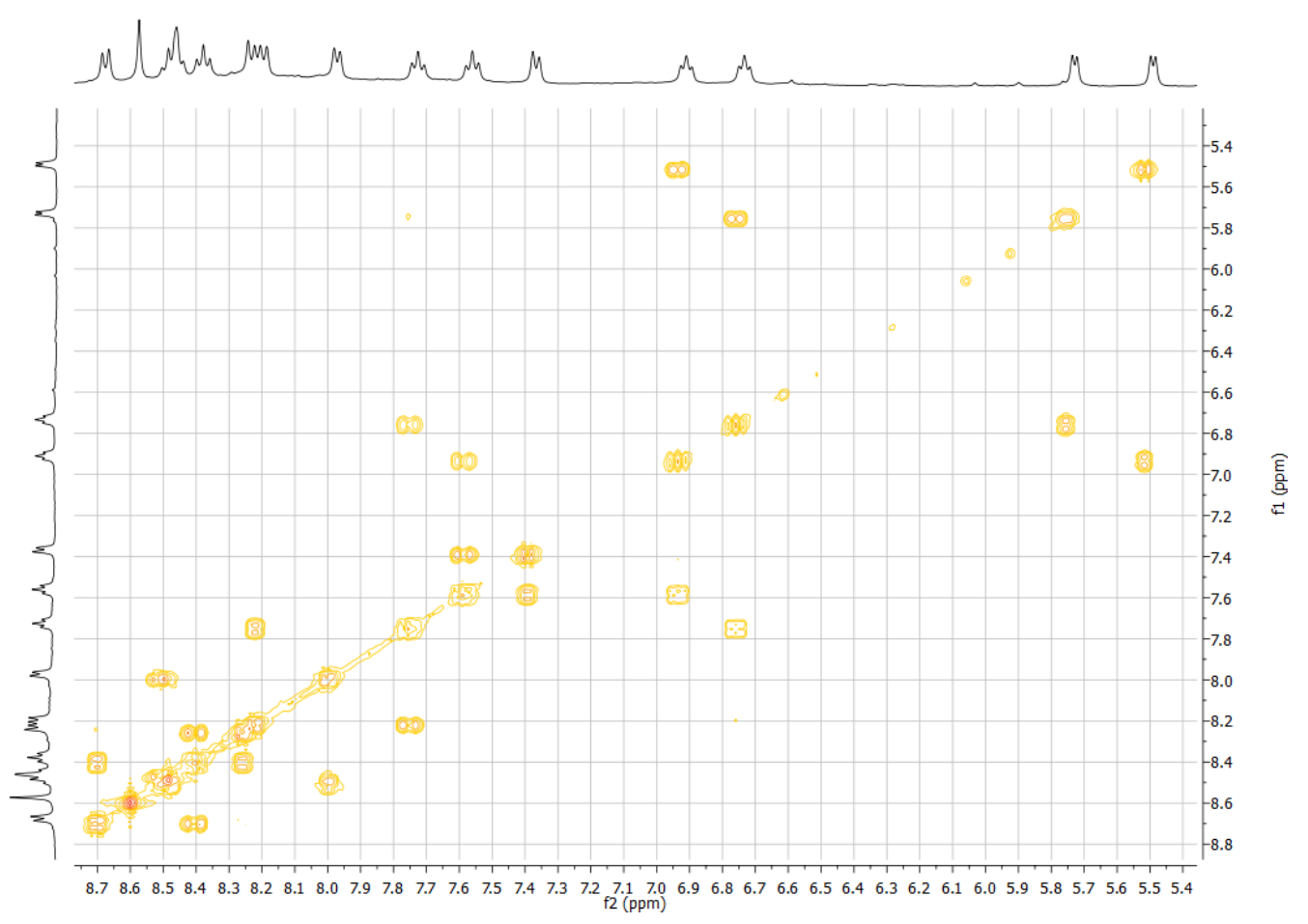

Figure S5. ${ }^{1} \mathrm{H}-{ }^{1} \mathrm{H}$ COSY on $\left[\mathrm{L}_{4} \mathrm{Ru}_{2} \mathrm{Co}_{2}\right]\left(\mathrm{BF}_{4}\right)_{6}(3)$ in $\mathrm{MeCN}-\mathrm{d}_{3}$ at room temperature. 


\section{EPR Spectroscopy}
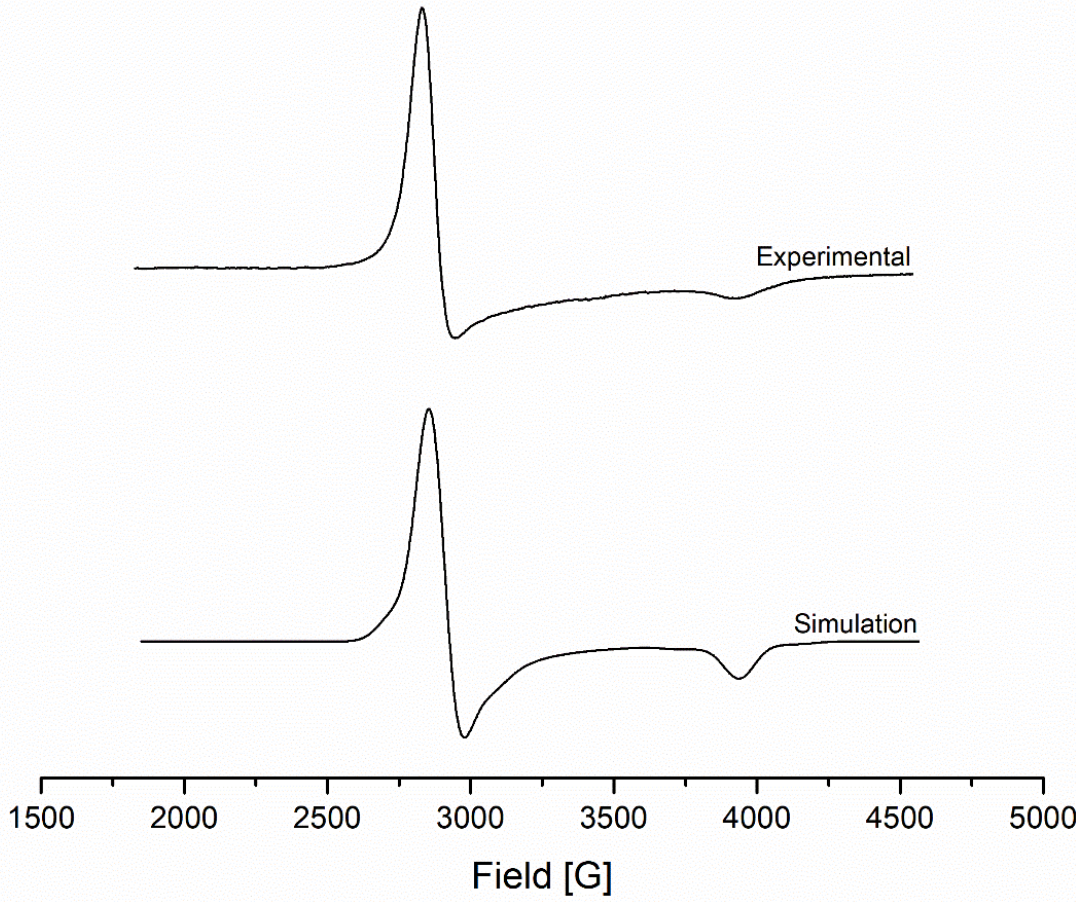

Figure S6. X-band EPR spectroscopy of $\mathbf{1}^{\mathbf{3 +}}$ in frozen acetonitrile (144 K) generated in situ by addition an excess of $\mathrm{NOBF}_{4}$. Microwave frequency $9.42 \mathrm{GHz}$, power level $9.87 \mathrm{~mW}$, modulation frequency $100 \mathrm{kHz}$, modulation amplitude $4.00 \mathrm{G}$. Simulation using EasySpin ${ }^{2}$ affords $g_{1}=g_{2}=$ 2.40 and $g_{3}=1.78$. 


\section{Cyclic Voltammetry}

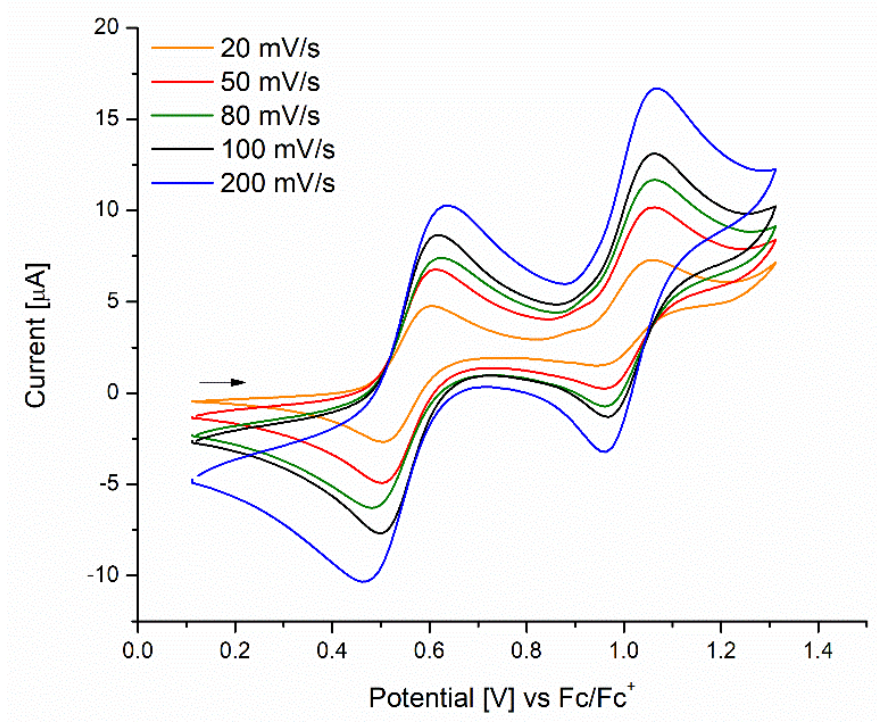

Figure S7. Cyclic voltammogram of $\mathbf{1}$ at different scan rates with $\left[\mathrm{Bu}_{4} \mathrm{~N}\right] \mathrm{PF}_{6}$ as the conducting salt. All potentials are referenced against $\mathrm{Fc} / \mathrm{Fc}^{+}$.

Table S2. Electrochemical parameters for the first oxidation of $\mathbf{1}$ at different scan rates.

\begin{tabular}{ccccc}
\hline $\begin{array}{c}\text { scan rate } \\
{\left[\mathrm{mV} \cdot \mathrm{s}^{-1}\right]}\end{array}$ & $E_{\text {ox }}[\mathrm{mV}]$ & $E_{\text {red }}[\mathrm{mV}]$ & $E_{1 / 2}[\mathrm{mV}]$ & $\Delta E_{\mathrm{p}}[\mathrm{mV}]$ \\
\hline 20 & 604 & 502 & 553 & 102 \\
50 & 616 & 504 & 560 & 112 \\
80 & 624 & 488 & 556 & 136 \\
100 & 616 & 496 & 556 & 120 \\
200 & 640 & 460 & 550 & 180 \\
\hline
\end{tabular}

Table S3. Electrochemical parameters for the second oxidation of $\mathbf{1}$ at different scan rates.

\begin{tabular}{ccccc}
\hline $\begin{array}{c}\text { scan rate } \\
{\left[\mathrm{mV} \cdot \mathrm{s}^{-1}\right]}\end{array}$ & $E_{\text {ox }}[\mathrm{mV}]$ & $E_{\text {red }}[\mathrm{mV}]$ & $E_{1 / 2}[\mathrm{mV}]$ & $\Delta E_{\mathrm{p}}[\mathrm{mV}]$ \\
\hline 20 & 1060 & 965 & 1012 & 96 \\
50 & 1064 & 961 & 1013 & 104 \\
80 & 1064 & 961 & 1013 & 104 \\
100 & 1064 & 969 & 1017 & 96 \\
200 & 1072 & 965 & 1018 & 108 \\
\hline
\end{tabular}



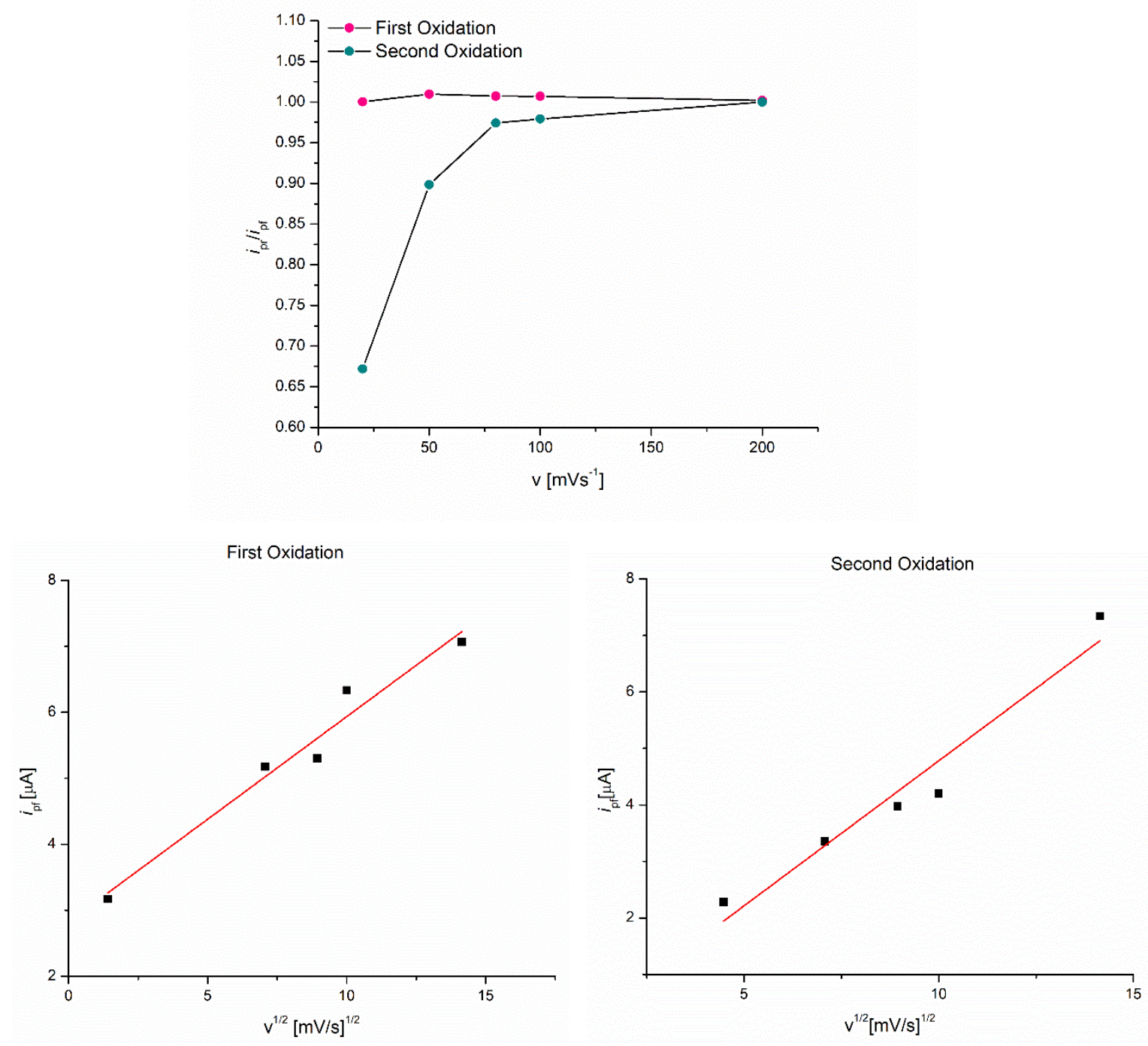

Figure S8. Top: Graph of $i_{\mathrm{pr}} / i_{\mathrm{pf}}$ versus $v$ for the first and second oxidation of the $\mathrm{Ru}$ " "corner complex" 1 ( $i_{\mathrm{pr}}$ is the peak current of the reverse scan and $i_{\mathrm{pf}}$ is the peak current of the reverse scan. Bottom: Plot of the $i_{\text {pf }}$ versus $v^{1 / 2}$ for the first (left) and second (right) oxidation of the $\mathrm{Ru}^{\mathrm{II}}$ "corner complex" 1. 


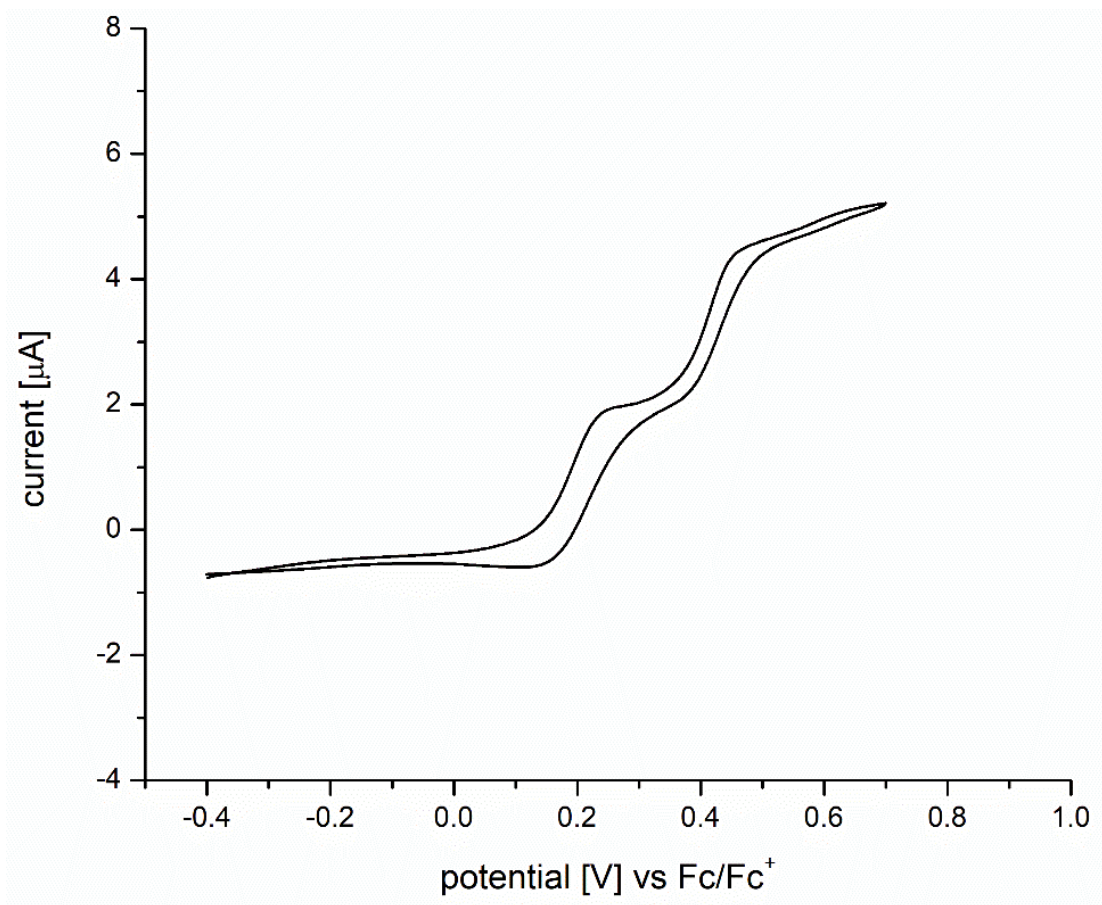

Figure S9. Cyclic voltammogram of 2 at $2 \mathrm{mV} / \mathrm{s}$ revealing the two anodic and cathodic waves. 


\section{Spectro-electrochemistry}

(a)

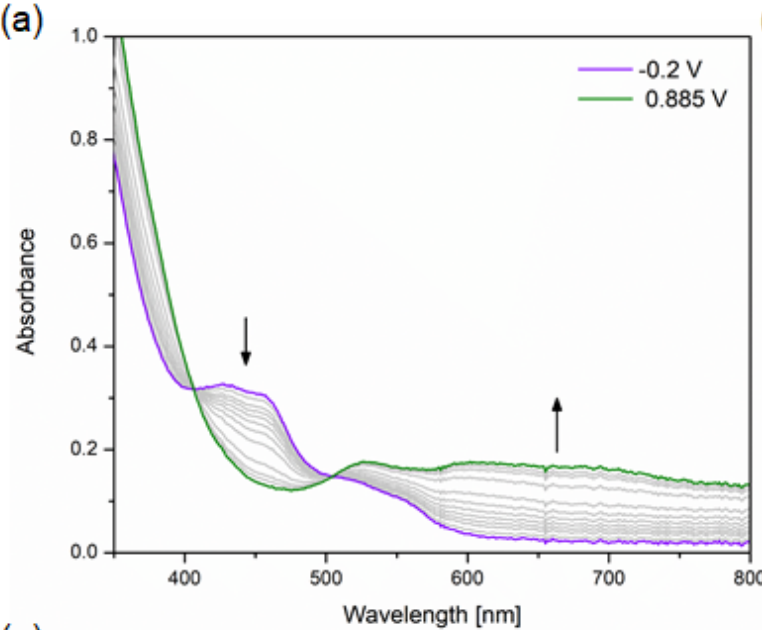

(c)

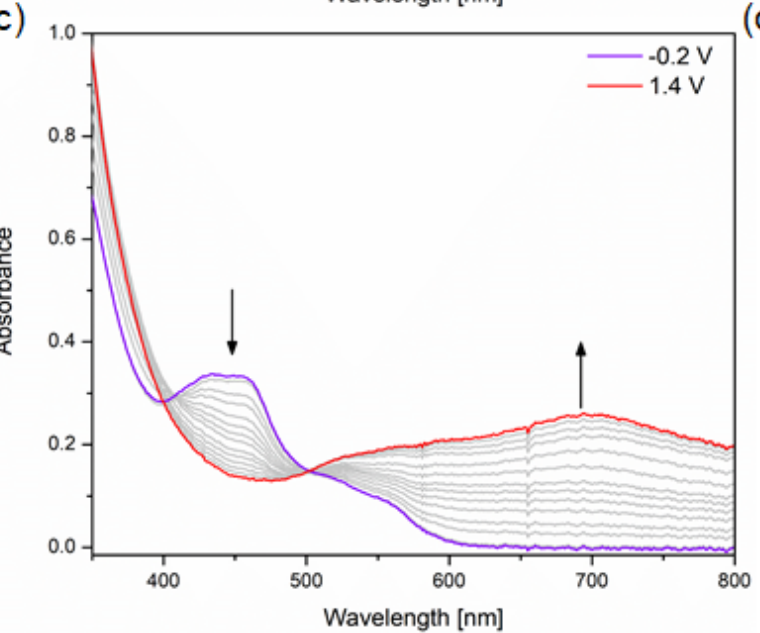

(b)

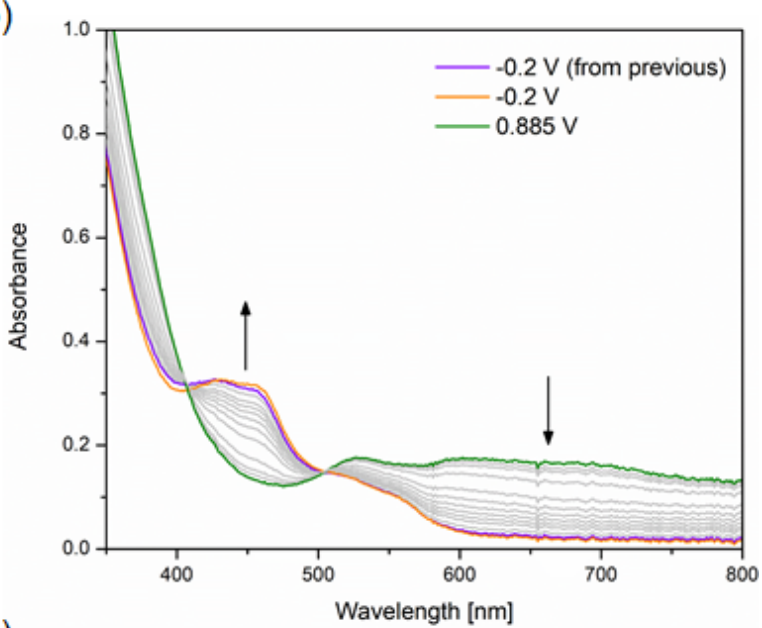

(d)

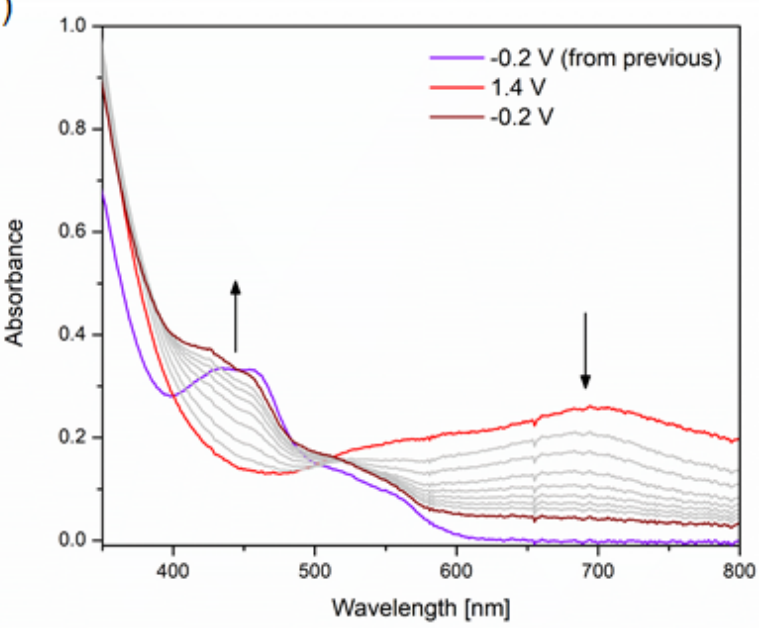

Figure S10. (a) UV-Vis spectroelectrochemistry of 1 at $0.885 \mathrm{~V}$ (first oxidation) and (b) the reverse reduction at $-0.2 \mathrm{~V}$. (c) UV-vis spectroelectrochemistry of $\mathbf{1}$ to the second oxidative wave $(1.4 \mathrm{~V})$ followed by $(\mathrm{d})$ reduction to the original species $(-0.2 \mathrm{~V})$. All potentials are referenced to $\mathrm{Fc} / \mathrm{Fc}^{+}$. 
(a)

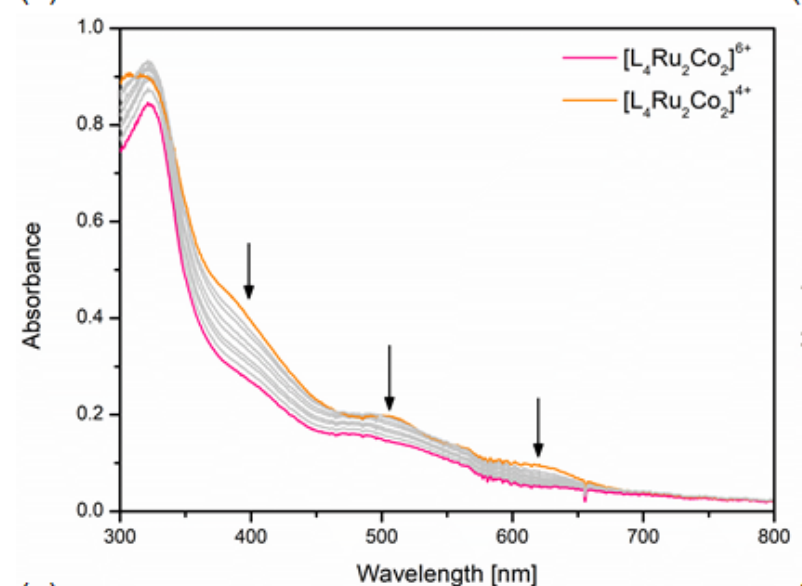

(c)

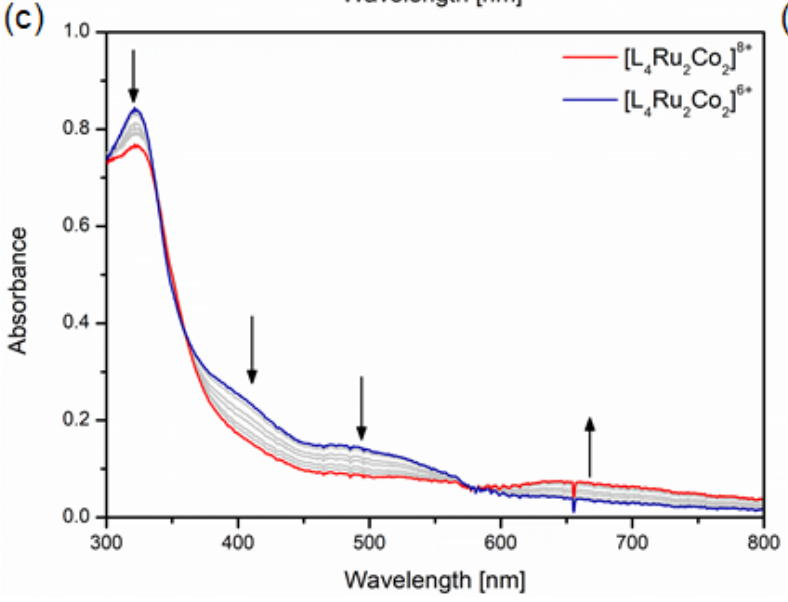

(b)

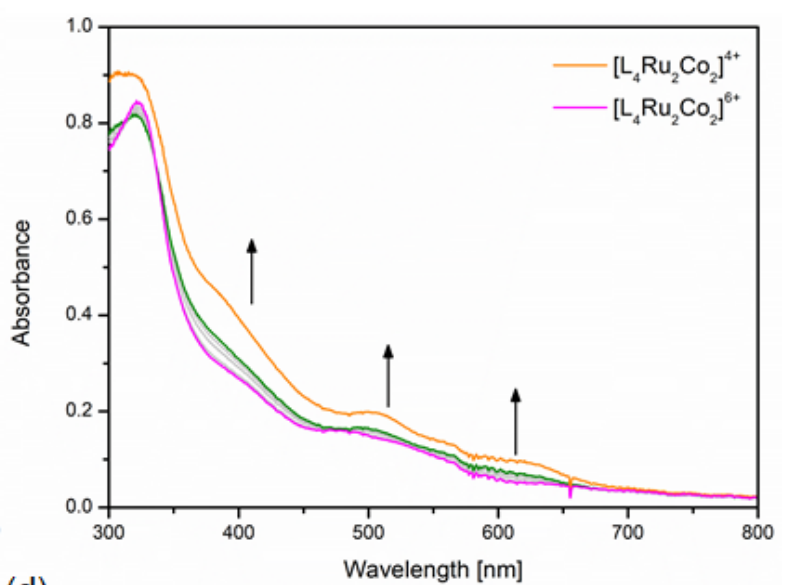

(d)

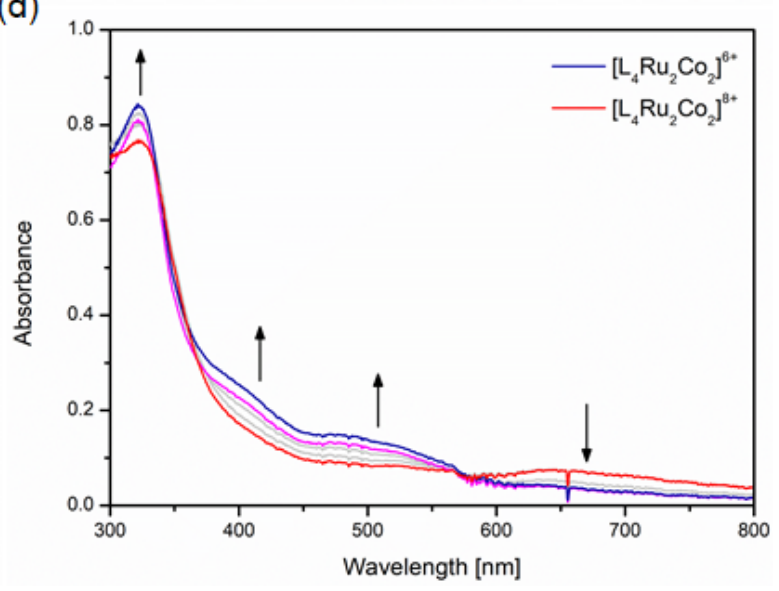

Figure S11. UV-Vis spectroelectrochemistry of (a) the oxidation $\left[\mathrm{L}_{4} \mathrm{Ru}_{2} \mathrm{Co}_{2}\right]^{4+} \rightarrow\left[\mathrm{L}_{4} \mathrm{Ru}_{2} \mathrm{Co}_{2}\right]^{6+}$ and (b) the re-reduction to the original $\left[\mathrm{L}_{4} \mathrm{Ru}_{2} \mathrm{Co}_{2}\right]^{4+}$ grid after reversing the potential. (c) $\mathrm{UV}$-vis spectroelectrochemistry for the oxidation of mixed-valent $\left[\mathrm{L}_{4} \mathrm{Ru}_{2} \mathrm{Co}_{2}\right]^{6+}$ to fully oxidized $\left[\mathrm{L}_{4} \mathrm{Ru}_{2} \mathrm{Co}_{2}\right]^{8+}$ and (d) during the reverse process back to the mixed-valent $\left[\mathrm{L}_{4} \mathrm{Ru}_{2} \mathrm{Co}_{2}\right]^{6+}$ grid. 


\section{X-Ray Crystallography}

X-ray data were collected on a STOE IPDS II diffractometer (graphite monochromated Mo-K $\alpha$ radiation, $\lambda=0.71073 \AA$ ) by use of scans at $-140{ }^{\circ} \mathrm{C}$ (Table S1). The structures were solved with SHELXT ${ }^{[3]}$ and refined on $F^{2}$ using all reflections with SHELXL-2018. ${ }^{[4]}$ Most nonhydrogen atoms were refined anisotropically. Hydrogen atoms were placed in calculated positions and assigned to an isotropic displacement parameter of $1.2 / 1.5 U_{\text {eq }}(\mathrm{C})$ or $1.2 U_{\text {eq }}(\mathrm{N})$. Most of the $\mathrm{BF}_{4}{ }^{-}$anions have been found disordered in all structures: $1=4$ out of 4 (occupancy factors: 0.163(14)/0.837(14), 0.181(13)/0.819(13), 0.621(10)/0.379(10), 0.461(9)/0.539(9)), 2 $=3$ out of 4 (occupancy factors: 0.828(5)/0.172(5), 0.841(5)/0.159(5), 0.249(11)/ 0.751(11)). In case of 3 one $\mathrm{BF}_{4}^{-}$is not disordered a second $\mathrm{BF}_{4}^{-}$shows a positional disorder (occupancy factors: $0.767(8) / 0.233(8)$ ), and the remaining anions are disordered about a two-fold rotation axis together with a MeCN solvent molecule. The occupancy factors were fixed at $2 \times 0.5,1 \mathrm{x}$ $0.2,2 \times 0.15$ for the $\mathrm{BF}_{4}^{-}$and 0.5 for the $\mathrm{MeCN}$. This part of the disorder was refined isotropically. A further MeCN solvent molecule in $\mathbf{3}$ was found to be disordered about a twofold rotation axis and was refined at $1 / 2$ occupancy. SADI $(d(\mathrm{~B}-\mathrm{F}), d(\mathrm{~F} \cdots \mathrm{F}))$, SIMU, DELU, RIGU restraints and EADP constraints were applied to model the disordered parts. The unit cells of 1 and $\mathbf{2}$ contain highly disordered solvent molecules (MeCN) for which no satisfactory model for a disorder could be found. The solvent contribution to the structure factors was calculated with PLATON SQUEEZE ${ }^{[5]}$ and the resulting .fab file was processed with SHELXL using the ABIN instruction. The empirical formula and derived values are in accordance with the calculated cell content. 1 was found to be twinned (twin-law: $0.249180 .75433-0.18964$, $1.24705-0.24837-0.18735,0.00435-0.00162-1.00124$; BASF: $0.245(1)$ ). Face-indexed absorption corrections were performed numerically with the program X-RED. ${ }^{[6]}$

CCDC 1937044-1937046 contain the supplementary crystallographic data for this paper. These data can be obtained free of charge from The Cambridge Crystallographic Data Centre via http://www.ccdc.cam.ac.uk/data_request/cif. 
Table S4. Crystal data and refinement details for 1, 2, and $\mathbf{3 .}$

\begin{tabular}{|c|c|c|c|}
\hline compound & 1 (jw-01-440_sq) & 2 (jw-355_sq) & 3 (jw-01-421) \\
\hline empirical formula & $\mathrm{C}_{94} \mathrm{H}_{67} \mathrm{~B}_{4} \mathrm{~F}_{16} \mathrm{~N}_{25} \mathrm{Ru}_{2}$ & $\mathrm{C}_{92} \mathrm{H}_{60} \mathrm{~B}_{4} \mathrm{Co}_{2} \mathrm{~F}_{16} \mathrm{~N}_{24} \mathrm{Ru}_{2}$ & $\mathrm{C}_{96} \mathrm{H}_{66} \mathrm{~B}_{6} \mathrm{Co}_{2} \mathrm{~F}_{24} \mathrm{~N}_{26} \mathrm{Ru}_{2}$ \\
\hline moiety formula & $\mathrm{C}_{92} \mathrm{H}_{64} \mathrm{~N}_{24} \mathrm{Ru}_{2}{ }^{4+}, 4\left(\mathrm{BF}_{4}^{-}\right), \mathrm{C}_{2} \mathrm{H}_{3} \mathrm{~N}$ & $\mathrm{C}_{92} \mathrm{H}_{60} \mathrm{Co}_{2} \mathrm{~N}_{24} \mathrm{Ru}_{2}{ }^{4+}, 4\left(\mathrm{BF}_{4}^{-}\right)$ & $\begin{array}{l}\mathrm{C}_{92} \mathrm{H}_{60} \mathrm{Co}_{2} \mathrm{~N}_{24} \mathrm{Ru}_{2}{ }^{6+}, 6\left(\mathrm{BF}_{4}^{-}\right), \\
2\left(\mathrm{C}_{2} \mathrm{H}_{3} \mathrm{~N}\right)\end{array}$ \\
\hline formula weight & 2096.10 & 2168.88 & 2424.60 \\
\hline crystal size $\left[\mathrm{mm}^{3}\right]$ & $0.50 \times 0.12 \times 0.10$ & $0.50 \times 0.48 \times 0.39$ & $0.24 \times 0.20 \times 0.17$ \\
\hline crystal system & triclinic & monoclinic & monoclinic \\
\hline space group & $P-1$ (No. 2) & $P 2_{1} / n$ (No. 14$)$ & $C 2 / c($ No. 15$)$ \\
\hline$a[\AA]$ & $13.8944(5)$ & $19.6906(3)$ & $22.2361(10)$ \\
\hline$b[\AA]$ & $17.1622(6)$ & $23.6818(3)$ & $21.1294(10)$ \\
\hline$c[\AA]$ & $21.3058(8)$ & $22.1913(3)$ & $20.3095(8)$ \\
\hline$\alpha\left[^{\circ}\right]$ & $84.379(3)$ & 90 & 90 \\
\hline$\beta\left[^{\circ}\right]$ & $80.806(3)$ & $96.802(1)$ & $91.847(3)$ \\
\hline$\gamma\left[{ }^{\circ}\right]$ & $82.125(3)$ & 90 & 90 \\
\hline$V\left[\AA^{3}\right]$ & $4952.9(3)$ & $10275.2(2)$ & $9537.2(7)$ \\
\hline$Z$ & 2 & 4 & 4 \\
\hline$\rho\left[\mathrm{g} \cdot \mathrm{cm}^{-3}\right]$ & 1.405 & 1.402 & 1.689 \\
\hline$F(000)$ & 2116 & 4344 & 4848 \\
\hline$\mu\left[\mathrm{mm}^{-1}\right]$ & 0.393 & 0.690 & 0.765 \\
\hline$T_{\min } / T_{\max }$ & 0.7094 / 0.9059 & $0.5360 / 0.6660$ & 0.8693 / 0.9829 \\
\hline$\theta$-range $\left[{ }^{\circ}\right]$ & $1.201-26.176$ & $1.351-25.859$ & $1.330-25.795$ \\
\hline$h k l$-range & $\pm 17, \pm 21, \pm 26$ & $\pm 23, \pm 28, \pm 27$ & $\pm 27, \pm 25, \pm 24$ \\
\hline measured refl. & 84099 & 127085 & 57798 \\
\hline unique refl. $\left[R_{\text {int }}\right]$ & 84099 & $19400[0.0333]$ & $9061[0.1566]$ \\
\hline observed refl. $(I>2 \sigma(I))$ & 44756 & 16209 & 4196 \\
\hline data / restr. / param. & 84099 / 472 / 1336 & 19400 / 354 / 1321 & $9061 / 141 / 764$ \\
\hline goodness-of-fit $\left(F^{2}\right)$ & 1.042 & 1.057 & 1.054 \\
\hline$R 1, w R 2(I>2 \sigma(I))$ & $0.0755 / 0.1945$ & $0.0461 / 0.1266$ & $0.0805 / 0.2087$ \\
\hline$R 1, w R 2$ (all data) & $0.1490 / 0.2314$ & $0.0563 / 0.1361$ & $0.1852 / 0.2837$ \\
\hline res. el. dens. $\left[\mathrm{e} \cdot \AA^{-3}\right]$ & $-0.886 / 1.200$ & $-0.806 / 0.777$ & $-0.716 / 0.893$ \\
\hline
\end{tabular}




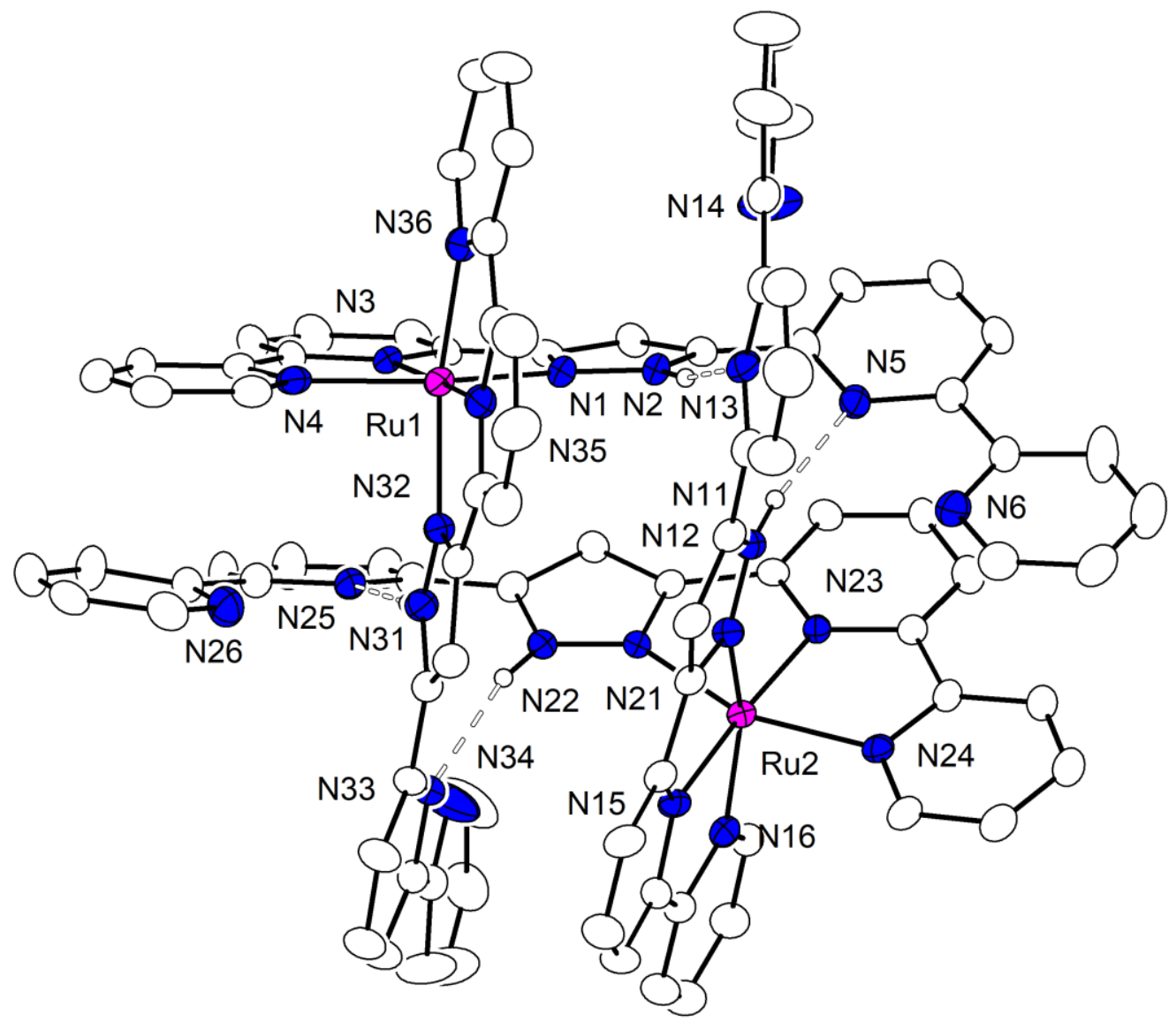

Figure S12. Plot of the molecular structure of the cation of $\mathbf{1}$ (30\% probability thermal ellipsoids; hydrogen atoms omitted for clarity). Selected bond lengths $[\AA]$ and angles $\left[{ }^{\circ}\right]$ for 1: Ru1-N35 1.979(7), Ru1-N3 1.982(7), Ru1-N36 2.047(7), Ru1-N1 2.068(7), Ru1-N32 2.071(6), Ru1-N4 2.076(7), Ru2-N23 1.985(6), Ru2-N15 1.999(6), Ru2-N16 2.047(6), Ru2-N24 2.060(6), Ru2-

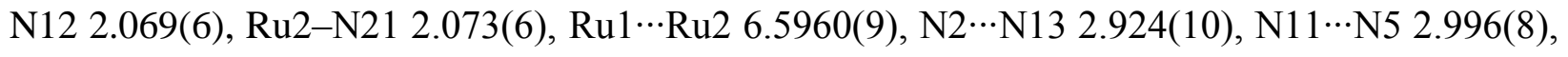

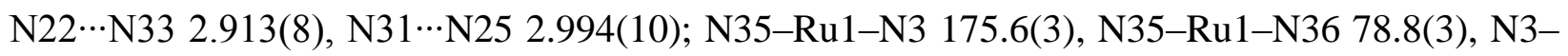
Ru1-N36 100.6(3), N35-Ru1-N1 106.5(3), N3-Ru1-N1 77.9(3), N36-Ru1-N1 88.4(3), N35Ru1-N32 77.8(3), N3-Ru1-N32 102.9(3), N36-Ru1-N32 156.5(3), N1-Ru1-N32 96.2(2), N35Ru1-N4 97.0(3), N3-Ru1-N4 78.6(3), N36-Ru1-N4 95.1(3), N1-Ru1-N4 156.5(3), N32-Ru1N4 89.8(2), N23-Ru2-N15 175.8(3), N23-Ru2-N16 101.7(2), N15-Ru2-N16 78.3(3), N23Ru2-N24 79.1(2), N15-Ru2-N24 96.8(3), N16-Ru2-N24 94.6(2), N23-Ru2-N12 101.9(2), N15-Ru2-N12 78.1(2), N16-Ru2-N12 156.4(2), N24-Ru2-N12 89.1(2), N23-Ru2-N21 77.4(2), N15-Ru2-N21 106.8(3)， N16-Ru2-N21 89.7(2)， N24-Ru2-N21 156.4(2)， N12-Ru2-N21 96.2(2). 


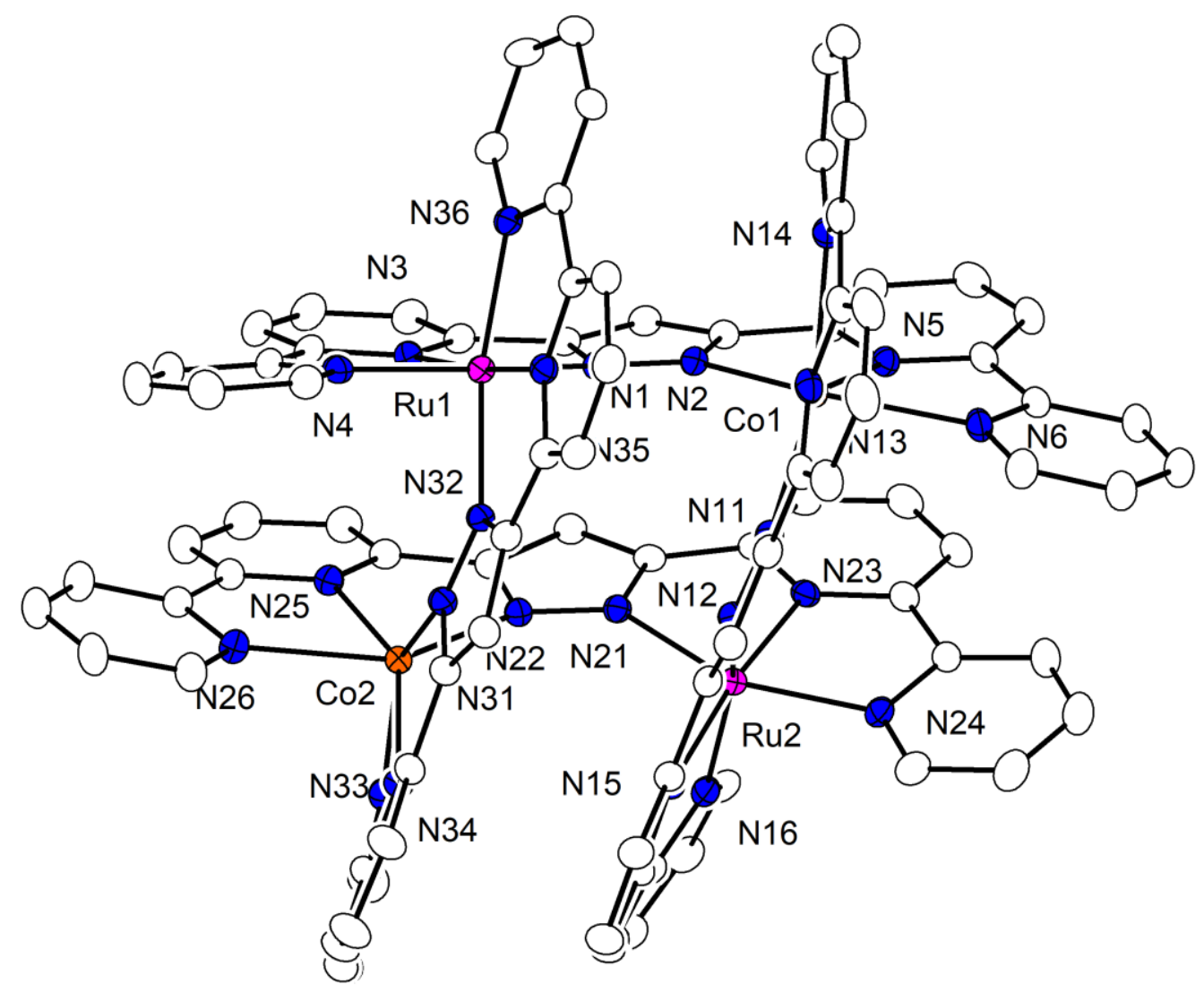

Figure S13. Plot of the molecular structure of the cation of 2 (30\% probability thermal ellipsoids; hydrogen atoms omitted for clarity). Selected bond lengths $[\AA]$ and angles $\left[{ }^{\circ}\right]$ for 2: Ru1-N35 1.982(3), Ru1-N3 1.986(3), Ru1-N4 2.059(3), Ru1-N36 2.065(3), Ru1-N32 2.069(3), Ru1-N1 2.075(3), Ru2-N15 1.999(3), Ru2-N23 2.004(3), Ru2-N16 2.086(3), Ru2-N24 2.087(3), Ru2N21 2.098(3), Ru2-N12 2.105(3), Co1-N13 2.077(3), Co1-N5 2.079(3), Co1-N11 2.098(3), Co1-N2 2.123(3), Co1-N14 2.249(3), Co1-N6 2.307(3), Co2-N33 2.068(3), Co2-N25 2.082(3), Co2-N22 2.098(3), Co2-N31 2.116(3), Co2-N34 2.305(3), Co2-N26 2.313(3), Ru1Ru2

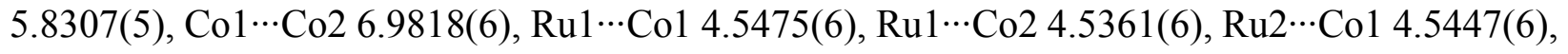
Ru2‥Co2 4.5649(6); N35-Ru1-N3 172.87(12), N35-Ru1-N4 96.64(12), N3-Ru1-N4 78.78(12), N35-Ru1-N36 78.83(12), N3-Ru1-N36 96.23(12), N4-Ru1-N36 97.38(11), N35-Ru1-N32 78.61(11), N3-Ru1-N32 106.28(11), N4-Ru1-N32 85.65(11), N36-Ru1-N32 157.43(12), N35Ru1-N1 105.56(11), N3-Ru1-N1 78.98(11), N4-Ru1-N1 157.75(12), N36-Ru1-N1 85.71(11), N32-Ru1-N1 99.95(11), N15-Ru2-N23 171.40(11), N15-Ru2-N16 78.29(12), N23-Ru2-N16 94.89(12), N15-Ru2-N24 98.00(12), N23-Ru2-N24 77.91(12), N16-Ru2-N24 100.38(11), 
N15-Ru2-N21 105.96(11), N23-Ru2-N21 78.19(11), N16-Ru2-N21 83.65(11), N24-Ru2-N21 156.01(12), N15-Ru2-N12 77.78(11), N23-Ru2-N12 108.98(11), N16-Ru2-N12 156.06(12), N24-Ru2-N12 83.40(11), N21-Ru2-N12 102.55(11), N13-Co1-N5 150.32(11), N13-Co1-N11 77.67(11), N5-Co1-N11 122.13(11), N13-Co1-N2 124.69(11), N5-Co1-N2 78.11(11), N11Co1-N2 96.26(11), N13-Co1-N14 73.49(12), N5-Co1-N14 88.90(11), N11-Co1-N14 148.95(11), N2-Co1-N14 90.85(11), N13-Co1-N6 84.52(11), N5-Co1-N6 72.95(11), N11Co1-N6 94.16(11), N2-Co1-N6 150.48(11), N14-Co1-N6 94.30(11), N33-Co2-N25 147.54(12), N33-Co2-N22 124.80(11), N25-Co2-N22 78.22(11), N33-Co2-N31 78.00(11), N25-Co2-N31 124.86(11), N22-Co2-N31 98.44(11), N33-Co2-N34 73.02(11), N25-Co2-N34 86.18(11), N22-Co2-N34 89.10(11), N31-Co2-N34 148.90(11), N33-Co2-N26 85.44(11), N25-Co2-N26 72.39(12), N22-Co2-N26 149.45(11), N31-Co2-N26 91.67(11), N34-Co2-N26 96.98(11). 


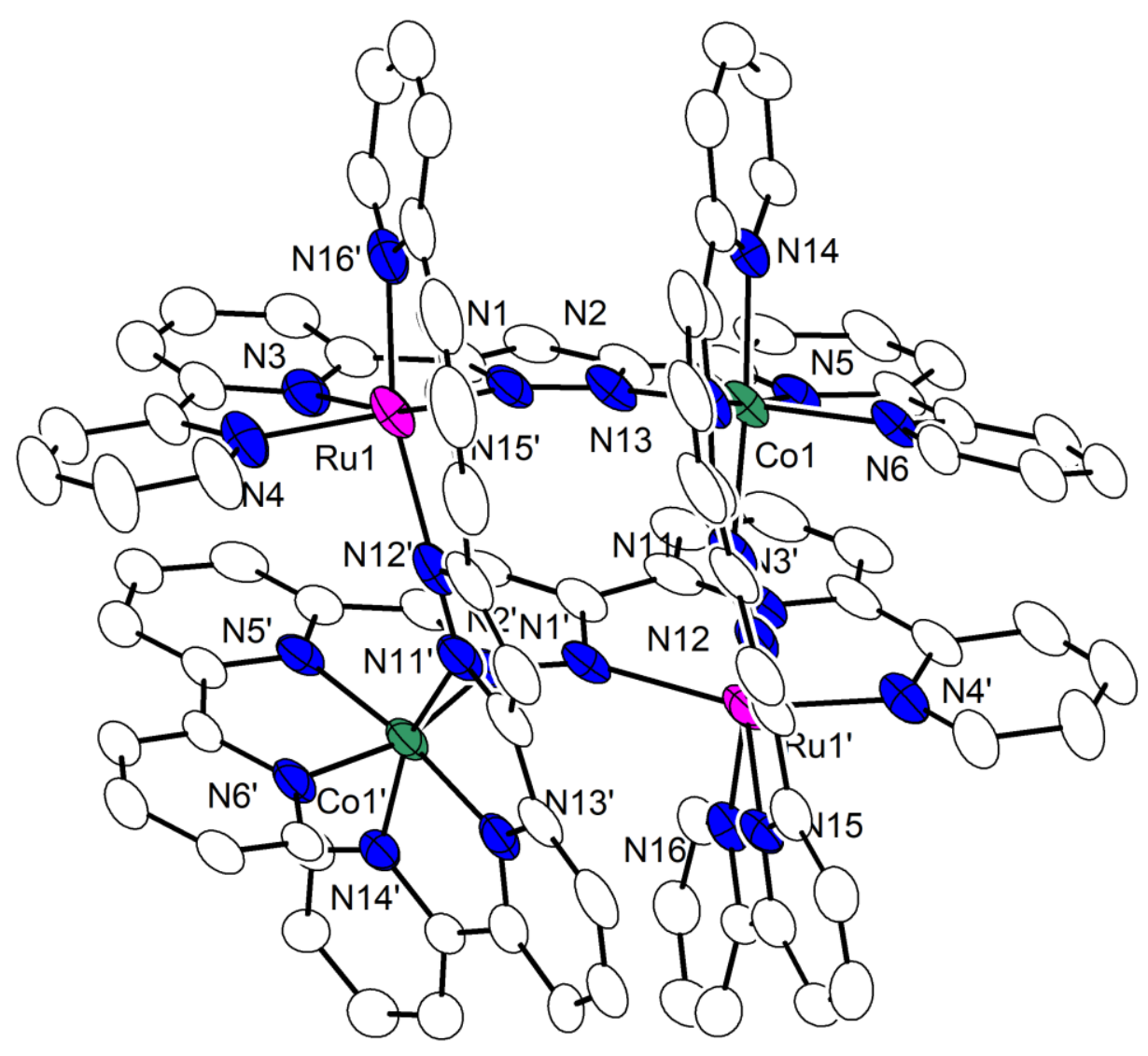

Figure S14. Plot of the molecular structure of the cation of $\mathbf{3}$ (30\% probability thermal ellipsoids; hydrogen atoms and disorder omitted for clarity). Selected bond lengths $[\AA]$ and angles $\left[{ }^{\circ}\right]$ for $\mathbf{3}$ : Ru1-N3 2.011(9), Ru1-N15' 2.015(9), Ru1-N16' 2.055(10), Ru1-N4 2.077(10), Ru1-N12' 2.142(10), Ru1-N1 2.176(9), Co1-N13 1.865(8), Co1-N5 1.888(8), Co1-N11 1.952(9), Co1-N2

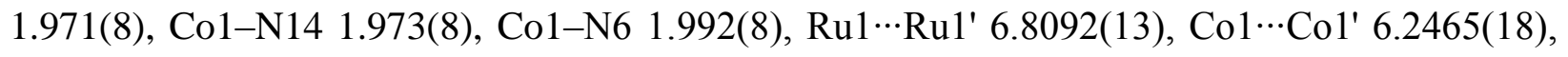

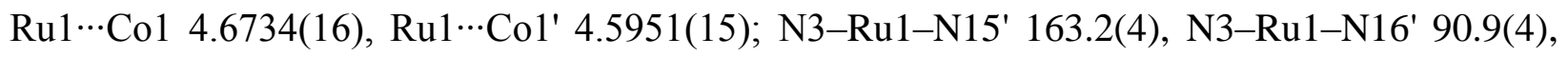
N15'-Ru1-N16' 78.0(4), N3-Ru1-N4 77.9(4), N15'-Ru1-N4 90.4(4), N16'-Ru1-N4 94.4(4), N3-Ru1-N12' 114.0(3)， N15'-Ru1-N12' 77.6(4)， N16'-Ru1-N12' 155.1(4)， N4-Ru1-N12' 90.6(4), N3-Ru1-N1 78.4(4), N15'-Ru1-N1 113.7(3), N16'-Ru1-N1 90.1(3), N4-Ru1-N1 155.9(4), N12'-Ru1-N1 95.2(3), N13-Co1-N5 172.4(3), N13-Co1-N11 82.4(4), N5-Co1-N11 102.4(4), N13-Co1-N2 102.5(3), N5-Co1-N2 83.0(3), N11-Co1-N2 95.2(3), N13-Co1-N14 81.9(4), N5-Co1-N14 93.1(3), N11-Co1-N14 164.3(4), N2-Co1-N14 88.6(3), N13-Co1-N6 93.7(3), N5-Co1-N6 80.9(3), N11-Co1-N6 86.0(3), N2-Co1-N6 163.7(3), N14-Co1-N6 94.7(3). Symmetry transformation used to generate equivalent atoms: (') $1-x, y, 3 / 2-z$. 
Table S5. Selected bond lengths and atom distance $[\AA]$.

\begin{tabular}{lccc}
\hline & $\mathbf{1}$ & $\mathbf{2}$ & $\mathbf{3}$ \\
\hline $\mathrm{Ru}-\mathrm{N}$ & $1.979(7)-2.076(7)$ & $1.982(3)-2.105(3)$ & $2.011(9)-2.176(9)$ \\
$\mathrm{Co}-\mathrm{N}$ & - & $2.068(3)-2.313(3)$ & $1.865(8)-1.992(8)$ \\
$\mathrm{Ru} \cdots \mathrm{Ru}$ & $6.5960(9)$ & $5.8307(5)$ & $6.8092(13)$ \\
$\mathrm{Co} \cdots \mathrm{Co}$ & - & $6.9818(6)$ & $6.2465(18)$ \\
$\mathrm{Ru} \cdots \mathrm{Co}$ & - & $4.5361(6)-4.5649(6)$ & $4.5951(15) / 4.6734(16)$ \\
\hline
\end{tabular}




\section{Magnetic Measurements}

Temperature-dependent magnetic susceptibility measurements were carried out with a QuantumDesign MPMS-XL-5 SQUID magnetometer equipped with a 5 Tesla magnet in the range from 2 to $210 \mathrm{~K}$ in a magnetic field of $0.5 \mathrm{~T}$. The polycrystalline sample was contained in a gel bucket, covered with a drop of low viscosity perfluoropolyether based inert oil Fomblin Y45 to prevent the crystals from moving and orienting, and fixed in a non-magnetic sample holder. The maximum measuring temperature of $210 \mathrm{~K}$ was chosen because of the pour point of the oil, in order to keep the oil in the frozen state and to avoid therefore the orientation of the crystals parallel to the magnetic field. Each raw data file for the measured magnetic moment was corrected for the diamagnetic contribution of the gel bucket and of the inert oil according to $M^{\text {dia }}=\chi_{\mathrm{g}} \cdot m \cdot H$, with experimentally obtained gram susceptibility of gel bucket $\left(\chi_{\mathrm{g}}=-5.70 \cdot 10^{-7} \mathrm{emu} /(\mathrm{g} \cdot \mathrm{Oe})\right.$ and of the oil $\left(\chi_{\mathrm{g}}=-3.82 \cdot 10^{-7} \mathrm{emu} /(\mathrm{g} \cdot \mathrm{Oe})\right)$. The molar susceptibility data were corrected for the diamagnetic contribution according to $\chi_{\mathrm{M}}^{\mathrm{dia}}($ sample $)=-0.5 \cdot M \cdot 10^{-6} \mathrm{~cm}^{3} \cdot \mathrm{mol}^{-1} \cdot{ }^{[7]}$

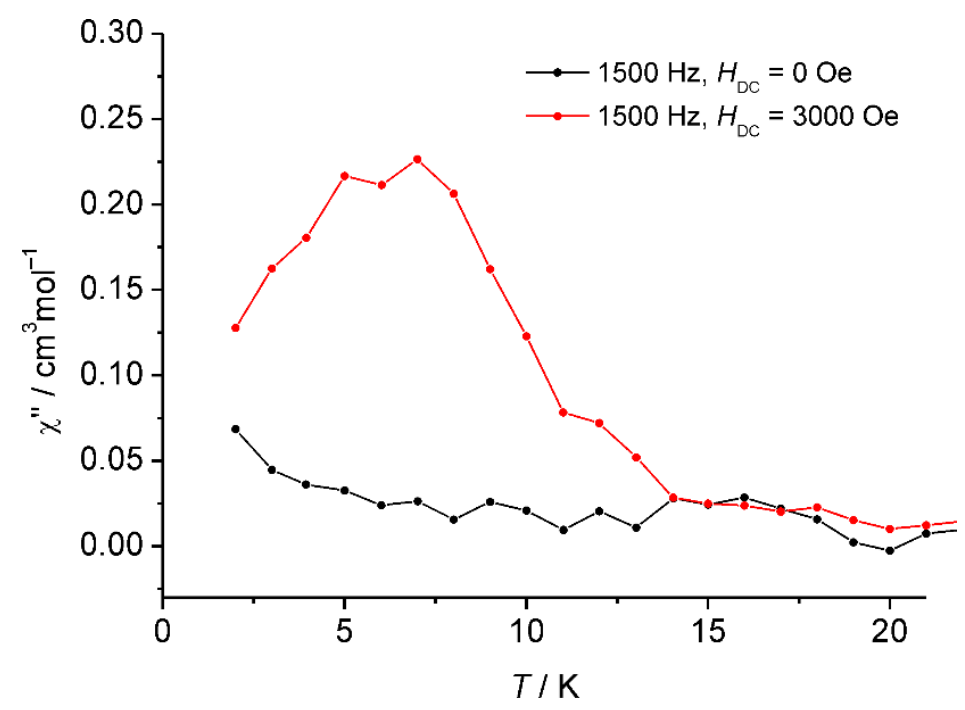

Figure S15. Temperature dependence of $\chi$ " at $1500 \mathrm{~Hz}$ in the absence of a dc field and with the applied dc field $H_{\mathrm{dc}}=3000$ Oe. 


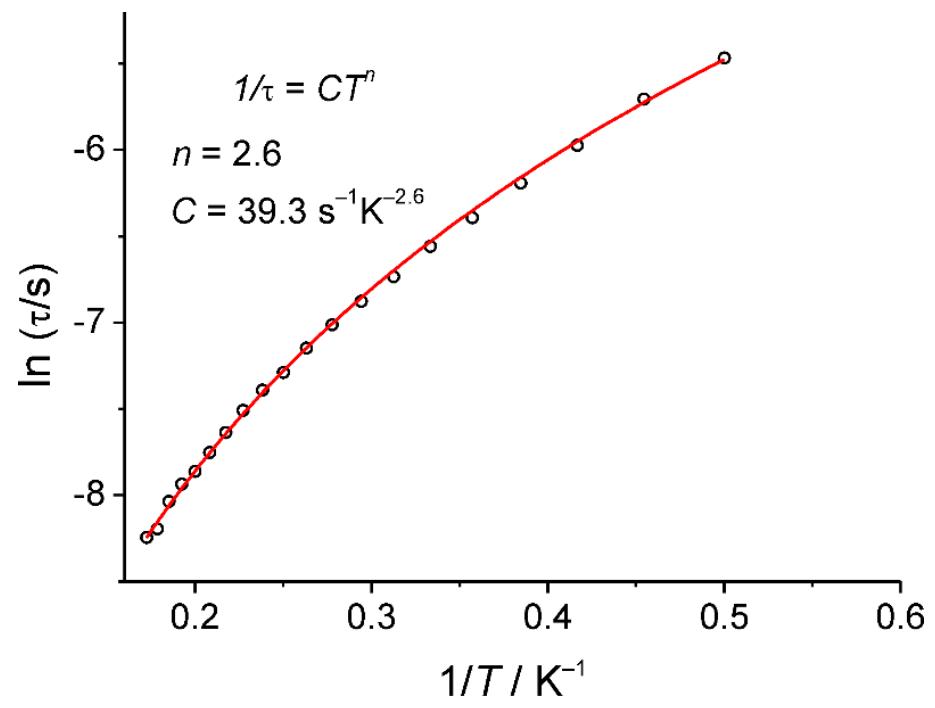

Figure S16. Relaxation times vs. inverse temperature for $\mathbf{2}$, fitted according to Raman relaxation $1 / \tau=C T^{n}$

\section{References}

[1] J. I. van der Vlugt, S. Demeshko, S. Dechert, F. Meyer, Inorg. Chem. 2008, 47, 1576-1585.

[2] S. Stoll, A. Schweiger, J. Magn. Reson. 2006, 178, 42-55.

[3] G. M. Sheldrick, Acta Cryst. 2015, A71, 3-8.

[4] G. M. Sheldrick, Acta Cryst. 2015, C71, 3-8.

[5] A. L. Spek, Acta Cryst. 2015, C71, 9-18.

[6] X-RED; STOE \& CIE GmbH: Darmstadt, Germany, 2002.

[7] O. Kahn, Molecular Magnetism, VCH Publishers Inc., New York, 1993. 